DOI: https://doi.org/10.24127/ajpm.v9i4.3124

\title{
PROSES BERPIKIR MAHASISWA DALAM MENYELESAIKAN MASALAH MATEMATIKA EKONOMI DITINJAU DARI KECERDASAN LOGIS MATEMATIS
}

\author{
Asmaul Husna $^{1 *}$, Yudhi Hanggara ${ }^{2}$, Nina Agustyaningrum ${ }^{3}$ \\ ${ }^{1 * 2,3}$ Pendidikan Matematika, Universitas Riau Kepulauan, Batam, Indonesia \\ *Corresponding author \\ E-mail: $\quad$ asmaul@fkip.unrika.ac.id $^{\left.{ }^{*}\right)}$ \\ yudhihanggara@gmail.com ${ }^{2)}$ \\ nina@fkip.unrika.ac.id ${ }^{3)}$
}

Received 30 September 2020; Received in revised form 28 November 2020; Accepted 27 December 2020

\begin{abstract}
Abstrak
Proses berpikir mahasiswa dalam menyelesaikan masalah matematika berbeda setiap individunya, salah satu faktornya adalah kecerdasan logis matematis. Penelitian ini bertujuan untuk mendeskripsikan proses berpikir mahasiswa semester VI Program studi pendidikan matematika Universitas Riau kepulauan dalam menyelesaikan masalah matematika berdasarkan langkah-langkah Polya ditinjau dari kecerdasan logis matematis. Penelitian ini merupakan penelitian deskriptif kualitatif. Pengumpulan data dalam penelitian ini dilakukan dengan menggunakan tes kecerdasan logis matematis, pemecahan masalah ekonomi dan wawancara. Teknik keabsahan data yang digunakan pada penelitian ini adalah triangulasi waktu. Teknik analisis data yang digunakan adalah konsep Miles dan Huberman, yaitu reduksi data, penyajian data, dan penarikan kesimpulan. Hasil penelitian ini mahasiswa dengan kecerdasan logis matematis tinggi dalam memahami masalah, merencanakan penyelesaian, melaksanakan penyelesaian, dan melihat kembali melakukan proses berpikir asimilasi. Proses berpikir siswa dengan kecerdasan logis matematis sedang dalam memahami masalah dan merencanakan masalah melakukan proses berpikir asimilasi, sedangkan untuk melaksanakan rencana penyelesaian dan melihat kembali melakukan proses berpikir akomodasi. Kemudian untuk mahasiswa dengan kecerdasan logis matematis rendah dalam memahami masalah, merencanakan penyelesaian, melaksanakan rencana penyelesaian dan melihat kembali melakukan proses berpikir akomodasi.
\end{abstract}

Kata kunci: kecerdasan logis matematis; matematika ekonomi; pemecahan masalah matematis; proses berpikir.

\begin{abstract}
The thinking process in solving Math problems is different one another due to their mathematical logical intelligence. This study aims at describing the thinking process among the sixth semester students of Mathematics Education Study Program, Riau Kepulauan Unversity based on Polya's steps on students' logical-mathematical intelligence. This research can be categorized as qualitative descriptive study. Data collection was done using Math logical intelligence tests, economic problem-solving and interviews. The data validity technique used triangulation of time. The data analysis technique adopted Miles and Huberman concept, i.e. data reduction, data presentation, and conclusion making. The results of this study revealed that the students with high mathematical logical intelligence for solving Mathematical economics in understanding problems, planning solutions, performing solutions and reviewing showed an assimilation thinking process. The moderate mathematical logical intelligence students in understanding and planning the problem are performing an assimilation thinking process, while in executing the plan and reviewing was using an accommodation thinking process. The students with low mathematical logical intelligence in understanding problems, planning solutions, implementing the completion plans and reviewing employed an accommodation thinking process.
\end{abstract}

Keywords: mathematical economics ; mathematical logical intelligence; mathematical problem solving; thinking process.

This is an open access article under the Creative Commons Attribution 4.0 International License 
DOI: https://doi.org/10.24127/ajpm.v9i4.3124

\section{PENDAHULUAN}

Semakin berkembangnya ilmu pengetahuan dan teknologi menuntut dosen dan mahasiswa untuk meningkatkan kemampuannya dalam memecahkan masalah yang dihadapi. Pemecahan masalah merupakan kemampuan yang sangat penting dimiliki oleh setiap orang. Pemecahan masalah adalah suatu aktifitas yang dilakukan seseorang untuk menemukan solusi dari masalah yang diberikan (Yogi, 2015). Dalam menyelesaikan suatu masalah terjadi suatu proses berpikir sehingga seseorang dapat menemukan penyelesaian dari masalah yang diberikan.

Proses berpikir merupakan kegiatan yang terjadi dalam otak manusia. Informasi dan data ke otak diproses, sehingga apa yang ada di dalamnya membutuhkan adaptasi dan bahkan perubahan. Adaptasi terhadap skema baru dicapai melalui asimilasi atau akomodasi, tergantung pada jenis informasi yang masuk ke dalam struktur mental (Sopamena, 2017). Selain itu proses berpikir terjadi antara pengolahan informasi yang masuk dengan skema (struktur kognitif) yang ada di otak manusia. Ketika seseorang berinteraksi dengan hal yang baru maka akan terjadi proses adaptasi. Pada saat adaptasi struktur kognisi seseorang akan mengalami proses asimilasi atau akomodasi. Piaget mengatakan bahwa proses asimilasi dan akomodasi akan berlangsung terus menerus sampai terjadi keseimbangan (equilibrium) (Safrida, Susanto, \& Kurniati, 2015).

Asimilasi adalah proses individu dalam beradaptasi dan mengatur dirinya dengan lingkungan baru sehingga pemahaman akan berkembang. Sementara akomodasi terjadi ketika siswa tidak mampu menyerap pengalaman baru dengan skema yang mereka memiliki (Muhtarom, Murtianto, $\&$ Sutrisno, 2017). Selain itu asimilasi adalah proses kognitif yang terjadi ketika seseorang mengintegrasikan persepsi, konsep atau pengalaman baru ke dalam skema yang sudah ada dalam pikiran. Akomodasi adalah proses perubahan struktur kognitif sehingga dapat dipahami, jika struktur kognitif sudah di tempat harus disesuaikan dengan informasi yang diterima (Umainah \& Setyowati, 2020).

Dalam proses berpikir selalu berkaitan dengan kecerdasan bawaan, salah satunya adalah kecerdasan logis matematis. Kecerdasan logis matematis pada hakikatnya telah dimiliki oleh semua mahasiswa dengan tingkatan yang berbeda-beda. Gardner menjelaskan bahwa kecerdasan logis matematis mencakup tiga bidang yang saling berhubungan, yaitu: matematika, sains, dan logika (Hamzah, 2010).

Kecerdasan logis matematis adalah kemampuan seseorang dalam berpikir induktif dan deduktif, menyelesaikan masalah logika dan analitis, melakukan operasi matematis, dan melakukan penyelidikan ilmiah (Iskandar, 2012) Selanjutnya kecerdasan matematis logis menurut (Lunenburg \& Lunenburg, 2014) diartikan sebagai kepekaan dan kapasitas seseorang untuk membedakan pola logis atau numerik, serta kemampuan untuk menangani masalah penalaran. Senada dengan Lunenburg \& Lunenburg, (Mukarromah, 2019) berpendapat bahwa kecerdasan logis matematis merupakan gabungan dari perhitungan matematis yang sistematis dan bernalar.

siswa selalu beriringan dengan kemampuan pemahaman konsep, pengelolaan angka dan kemampuan mengoperasikan operasi hitung (Mukarromah, 2019). Kecerdasan logis 
matematis merupakan kecerdasan yang berkontribusi terhadap kemampuan pemecahan masalah (Arum, Kusmayadi, \& Pramudya, 2018; Suhendri, 2011; Karamikabir, 2012; Rahbarnia \& Hamedian, 2014; Ahvan, 2016) menyatakan bahwa tingkat kecerdasan logis matematis siswa memiliki pengaruh positif terhadap prestasi belajar siswa.

Hal ini menunjukkan bahwa semakin tinggi kecerdasan logis matematis siswa maka semakin baik kemampuan pemecahan masalah matematis. Kecerdasan logis matematis memiliki beberapa tingkatan yaitu rendah, sedang dan tinggi. Pada penelitian (Kamsari \& Winarso, 2018) menyimpulkan kemampuan pemecahan masalah matematika pada siswa dengan kecerdasan logis matematis tinggi termasuk kategori baik.

Penelitian proses berpikir dalam pemecahan masalah matematis telah banyak dilakukan dengan ditinjau dari berbagai aspek diantaranya penelitian yang dilakukan oleh (Yani, Ikhsan \& Marwan, 2016) ditinjau dari adversity quotient, (Khamidah \& Suherman, 2016) ditinjau dari kepribadian kersey, (Kurniawan, et al, 2017) ditinjau dari kecerdasan emosional, serta (Sanjaya, 2018) ditinjau dari kemampuan matematis siswa. Penelitian proses berpikir dalam pemecahan masalah matematis ditinjau dari kecerdasan logis matematis telah dilakukan (Faizah, Sujadi \& Setiawan, 2017) dalam penelitian ini proses berpikir dianalisis secara umum dan fokus pada kemampuan pemecahan masalah. Keterbaruan dalam penelitian ini yaitu proses berpikir dalam pemecahan masalah ditinjau dari kecerdasan logis matematis dengan lebih khusus meneliti komponen berpikir Asimilasi dan Akomodasi
Berdasarkan uraian di atas maka tujuan penelitian ini adalah untuk mendeskripsikan proses berpikir mahasiswa pada pemecahan masalah ditinjau dari kecerdasan logis matematis.

\section{METODE PENELITIAN}

Berdasakan tujuan dari penelitian yang dilakukan, maka penelitian ini dapat digolongkan sebagai penelitian deskriptif kualitatif yang berupaya mendeskripsikan proses berpikir mahasiswa dalam memecahkan masalah matematis berdasarkan langkah Polya ditinjau dari kecerdasan logis matematis pada mata kuliah Matematika Ekonomi. Data utama penelitian ini diperoleh dari penggunaan instrumen pertama berupa tes kecerdasan logis matematis bertujuan untuk menggolongkan level kecerdasan logis matematis mahasiswa, instrumen kedua berupa tes tertulis yang terdiri atas dua soal pada materi aplikasi turunan fungsi dalam ekonomi yang bertujuan untuk mengetahui kemampuan pemecahan masalah mahasiswa, dan instrumen ketiga berupa wawancara yang bertujuan untuk mengetahui proses berpikir mahasiswa.

Prosedur pengumpulan data pada penelitian ini, meliputi (a) memilih subjek penelitian ditinjau dari kecerdasan logis matematis, ditentukan dengan menggunakan tes. Tes ini terdapat 20 soal yang bertujuan untuk menggolongkan tingkat kecerdasan logis matematis mahasiswa. Analisis persentase tentang kecerdasan logis matematis mahasiswa dengan menggunakan rumus (1) (Magfiroh 2019):

$$
P=\frac{F}{N} \times 100 \%
$$

Keterangan:

$P=$ Persentase

$F=$ Frekuensi

$N=$ Banyaknya Responden 
DOI: https://doi.org/10.24127/ajpm.v9i4.3124

Setelah itu untuk mengetahui tingkat kecerdasan logis matematis mahasiswa data dikelompokkan berdasarkan tingkat ukuran kecerdasan logis matematis dengan kategori rendah, sedang, dan tinggi. Terlebih dahulu menentukan kelas interval, dengan rumus (2):

$$
\text { Kelas Interval }=\frac{(n t-n r)+1}{3} \ldots(2)
$$

Keterangan:

$n t=$ nilai tertinggi

$n r=$ nilai terendah

Dari data diperoleh:

$n t=18$

$n r=5$

$$
\frac{(18-5)+1}{3}=4.67 \approx 5
$$

(b) subjek yang dipilih satu mahasiswa dari tiap kategori tingkat kecerdasan logis-matematis dengan jawaban tes diagnostik yang lengkap kemudian diberikan tes tertulis tentang aplikasi turunan fungsi dalam ekonomi; (c) melakukan wawancara kepada subjek untuk mengetahui proses berpikir mahasiswa. Langkah selanjutnya setelah pengumpulan data adalah analisis data.

Tahap analisis data, ada beberapa proses yang dilakukan untuk menarik kesimpulan yang kredibel yaitu (a) Pada tahap reduksi data, data yang telah diperoleh dirangkum, dipilh hal-hal yang penting dan pokok yang dapat menunjang penelitian serta menghilangkan data yang tidak perlu; (b) tahap penyajian data, data yang telah direduksi kemudian diorganisasikan atau dikelompokkan ke dalam fokus tingkat kecerdasan logis matematis masingmasing sehingga terlihat perbedaan dari tingkat kecerdasan logis matematis terhadap pemecahan masalah berdasarkan langkah Polya; (c) kesimpulan dan verifikasi, kesimpulan awal yang telah diperoleh dari tahap reduksi dan penyajian data kemudian diperkuat dengan bukti-bukti yang kuat sehingga dapat ditarik suatu kesimpulan akhir yang selanjutnya data yang valid dan kredibel ini digunakan untuk mengidentifikasi proses berpikir siswa dalam memecahkan masalah matematika dengan tahapan Polya.

\section{HASIL DAN PEMBAHASAN}

1. Deskripsi Kecerdasan Logis

Berdasarkan skor angket, diperoleh hasil Frekuensi Kecerdasan Logis Matematis seperti Tabel 3.

Tabel 3. Frekuensi kecerdasan logis matematis.

\begin{tabular}{cccc}
$\begin{array}{c}\text { Interval } \\
\text { Nilai }\end{array}$ & Jumlah & $\begin{array}{c}\text { Persentase } \\
(\boldsymbol{\%})\end{array}$ & Ket. \\
\hline $5-9$ & 6 & 21.4 & Rendah \\
$10-14$ & 14 & 50 & Sedang \\
$15-19$ & 8 & 28.6 & Tinggi \\
\hline
\end{tabular}

Dari Tabel 3 dapat diambil kesimpulan bahwa mahasiswa dengan tingkat kecerdasan logis matematis rendah sebanyak 6 mahasiswa (21.4\%), tingkat sedang sebanyak 14 mahasiswa (50\%), sedangkan tingkat tinggi sebanyak 8 mahasiswa (28.6\%). Selanjutnya, hasil jawaban soal pemecahan masalah matematika ekonomi mahasiswa dianalisis proses berpikirnya berdasarkan kriteria menurut Piaget dengan dua cara yaitu asimilasi dan akomodasi.

Hasil penelitian ini berupa deskripsi tentang keterampilan proses berpikir mahasiswa berdasarkan dua kriteria berpikir oleh Piaget yaitu asimilasi dan akomodasi dalam menyelesaikan tes ditinjau dari level kecerdasan logis matematis tinggi, sedang dan rendah. Dari 3 level kecerdasan logis matematis tersebut dipilih satu perwakilan mahasiswa dari 
setiap kategori tingkat kecerdasan logismatematis dengan jawaban tes diagnostik yang lengkap. Selanjutnya mahasiswa yang dipilih tersebut diberi inisial DA (perwakilan mahasiswa memiliki kecerdasan logis matematis tinggi); DS (perwakilan mahasiswa memiliki kecerdasan logis sedang); RD (perwakilan mahasiswa memiliki kecerdasan logis matematis rendah). Berikut ini adalah analisis proses berfikir mahasiswa dari masing-masing kecerdasan logis matematis:

2. Deskripsi proses berpikir mahasiswa dengan kercerdasan logis matematis tinggi.

Mahasiswa DA melakukan proses berpikir asimilasi dalam memahami masalah, baik itu untuk soal a maupun soal b. Berdasarkan hasil wawancara dalam memahami masalah, mahasiswa DA dapat mengidentifikasi hal-hal yang diketahui dan ditanyakan pada soal dengan benar, meskipun mahasiswa DA tidak menuliskan sempurna apa yang diketahui dan ditanya dalam soal tersebut. Kemudian pada langkah merencanakan penyelesaian, mahasiswa DA melakukan proses berpikir asimilasi pada soal a dan soal $b$, berdasarkan hasil jawaban dan wawancara mahasiswa DA mampu menyebutkan konsep atau menjelaskan langkah dalam menyelesaikan masalah baik itu soal a dan soal $b$ dengan benar, dalam merencanakan penyelesaian mahasiswa DA mampu menuliskan dan menjelaskan kaidah turunan parsial dari Qx dan Qy terhadap Px dan Py berturut turut untuk mendapatkan fungsi permintaan marjinal pada fungsi permintaan dua jenis barang yang ada, serta mampu menginterpretasikan dengan kalimat sendiri kaidah turunan parsial yang didapatkan sesuai dengan hukum permintaan, mampu menyim- pulkan sifat hubungan kedua jenis barang berdasarkan hasil $\frac{\partial \mathrm{Qx}}{\partial \mathrm{Py}}$ dan $\frac{\partial \mathrm{Qy}}{\partial \mathrm{Px}}$.

Pada langkah selanjutnya yakni melaksanakan rencana penyelesaian, mahasiswa DA melakukan proses berpikir asimilasi pada soal a dan soal $b$. Berdasarkan jawaban dan wawancara, mahasiswa DA melaksanakan penyelesain masalah sesuai dengan rencana penyelesaian yang telah dibuat serta menggunakan kaidah turunan yang benar baik itu pada soal a dan soal $b$, mampu menuliskan dan menjelaskan dengan kalimat sendiri interpretasi dari hasil turunan yang didapat dan mampu menuliskan dan menjelaskan sifat hubungan kedua jenis barang tersebut dengan benar dan lengkap. Pada langkah terakhir yakni melihat kembali, mahasiswa DA melakukan proses berpikir asimilasi pada soal a dan soal $b$. Berdasarkan jawaban dan wawancara, mahasiswa DA mampu menunjukkan dan meyakinkan bahwa jawabannya benar. Pada soal a dan soal b, mahasiswa DA mampu membuktikan jawabannya benar dengan mengaitkan jawaban yang didapat dengan apa yang diketahui pada masalah tersebut.

3. Deskripsi proses berpikir mahasiswa dengan kercerdasan logis matematis sedang

Mahasiswa DS melakukan proses berpikir asimilasi dalam memahami masalah, baik itu untuk soal a maupun soal b. Berdasarkan hasil jawaban mahasiswa DS dan wawancara dalam memahami masalah, mahasiswa DS dapat mengidentifikasi hal-hal yang diketahui dan ditanyakan dalam soal a dan $b$ dengan benar. Hasil analisis berikutnya pada langkah menyusun rencana penyelesaian, mahasiswa DS melakukan proses berpikir asimilasi pada soal a dan b. Berdasarkan hasil jawaban dan wawancara, mahasiswa DS 
mampu menyebutkan konsep atau menjelaskan langkah dalam menyelesaikan soal a dan soal b. Pada soal a dan soal b mahasiswa DS dapat menyebutkan dan menuliskan dan menjelaskan kaidah turunan parsial dari Qx dan Qy terhadap Px dan Py berturut-turut untuk mendapatkan fungsi permintaan marjinal pada fungsi permintaan dua jenis barang yang diketahui pada soal dengan benar, meskipun alasan dalam menggunakan konsep tidak begitu sesuai. Pada kedua soal ini, mahasiswa DS mampu menjelaskan langkah dalam menyelesaikan masalah soal a dan soal b. Dalam merencanakan penyelesaian, mahasiswa DS dapat menyebutkan dan menuliskan dan menjelaskan kaidah turunan parsial dari Qx dan Qy terhadap Px dan Py berturut - turut untuk mendapatkan keempat fungsi permintaan marjinal pada fungsi permintaan dua jenis barang yang diketahui pada soal dengan benar.

Langkah selanjutnya yakni melaksanakan rencana penyelesaian, mahasiswa DS melakukan proses berpikir akomodasi pada soal a dan soal b. Berdasarkan jawaban dan wawancara, mahasiswa DS melaksanakan penyelesaian masalah sebagian tidak sesuai dengan rencana penyelesain yang telah dibuat serta dalam menggunakan algoritma mengarah pada jawaban yang benar untuk pertanyaan pertama soal a dan soal b. Pada soal a dan soal b mahasiswa DS menerapkan kaidah turunan parsial dari Qx dan Qy terhadap Px dan Py berturut - turut untuk mendapatkan keempat fungsi permintaan marjinal pada fungsi permintaan dua jenis barang, akan tetapi mahasiswa DS tidak menuliskan interpretasi dari keempat fungsi permintaan marjinal yang didapatkan, dan juga tidak menuliskan hubungan kedua jenis barang. Akan tetapi berdasarkan hasil wawancara mahasiswa DS mampu menginterpretasikan dengan kalimat sendiri kaidah turunan parsial yang didapatkan sesuai dengan hukum permintaan, mampu menyimpulkan sifat hubungan kedua jenis barang dari melihat dari tanda $\frac{\partial \mathrm{Qx}}{\partial \mathrm{Py}}$ dan $\frac{\partial \mathrm{Qy}}{\partial \mathrm{Px}}$ walaupun dengan penjelasan yang kurang lancar. Pada langkah melihat kembali, mahasiswa DS melakukan proses berpikir akomodasi pada soal a dan soal b. Berdasarkan jawaban dan wawancara, mahasiswa DS belum mampu membuktikan jawabannya, meskipun pekerjaan yang dilakukan sebagian benar.

4. Deskripsi proses berpikir mahasiswa dengan kercerdasan logis matematis rendah

Mahasiswa RD melakukan proses berpikir akomodasi dalam memahami masalah, baik itu untuk soal a dan soal b. Berdasarkan hasil jawaban mahasiswa dan wawancara dalam memahami masalah, mahasiswa RD dapat mengidentifiksi hal-hal yang diketahui dan tidak benar dalam mengidentifikasi yang ditanyakan dalam soal. Pada langkah menyusun rencana penyelesaian, mahasiswa RD melakukan proses berpikir akomodasi pada soal a dan soal b. Berdasarkan hasil jawaban dan wawancara, mahasiswa RD salah menyebutkan konsep atau menjelaskan langkah dalam menyelesaikan masalah pada soal. Pada soal mahasiswa RD tidak dapat menyebutkan konsep yang benar untuk digunakan dalam menyelesaikan masalah yakni seharusnya menggunakan konsep turunan parsial, akan tetapi konsep yang disebutkan adalah tentang mencari himpunan penyelesaian Sistem Persamaan Linear Dua Variabel (SPLDV) dengan metode eliminasi dan substitusi dan alasan dalam menggunakan konsep tidak sesuai. Pada 
soal a dan soal b mahasiswa RD tidak mampu menjelaskan langkah dalam menyelesaikan masalah tersebut. Dalam merencanakan penyelesaian, mahasiswa RD mengeliminasi fungsi permintaan yang diketahui, mahasiswa RD melakukan proses berpikir akomodasi pada soal a dan soal b. Berdasarkan jawaban dan wawancara, mahasiswa RD melaksanakan penyelesaian masalah sesuai dengan rencana penyelesaian yang telah dibuat, meskipun itu bukan merupakan jawaban yang benar. Kesimpulan akhirnya tidak sesuai dengan apa yang ditanyakan pada soal tersebut. Sehingga dapat disimpulkan bahwa mahasiswa RD melakukan proses berpikir akomodasi pada soal a dan soal b. Berdasarkan wawancara, mahasiswa RD belum mampu membuktikan jawabannya salah atau benar.

Berdasarkan uraian yang telah dijabarkan dapat disimpulkan bahwa mahasiswa dengan kecerdasan logis matematis tinggi mempunyai proses berpikir asimilasi. Hasil ini senada dengan penelitian (Masfingatin, 2013; Nafi'an and Ilman, 2012) melaporkan bahwa proses berpikir siswa dari kelompok tinggi cenderung berpikir asimilasi dalam menyelesaikan soal. Siswa dengan kecerdasan logis matematis tinggi cenderung memiliki ciri-ciri seperti mudah menganalisis dan mempelajari sebab akibat terjadinya sesuatu. Ia suka menyusun dalam kategori atau hierarki. Siswa semacam ini cenderung menyukai aktivitas berhitung dan memiliki kecepatan tinggi dalam menyelesaikan masalah matematika. Apabila kurang memahami, mereka akan cenderung berusaha untuk bertanya dan mencari jawaban atas hal yang kurang dipahaminya itu. Seseorang yang memiliki kecerdasan logis matematis yang tinggi akan berprestasi dalam pelajaran matematika dan menikmati kemajuan teknologi dalam penggunaan program software logika (Chatib, 2013), cenderung menyenangi kegiatan menganalisis dan mempelajari sebab akibat terjadinya sesuatu (Pane \& Kamid, 2013). Ia menyenangi berpikir secara konseptual, misalnya menyusun hipotesis dan mengadakan kategorisasi dan klasifikasi terhadap apa yang dihadapinya. Hal ini berarti bahwa mahasiswa yang mempunyai kecerdasan logis matematis tinggi mampu mengerjakan dan menyelesaikan soal pemecahan masalah serta mampu menyelesaikan dengan langkah-langkah yang sudah dipelajari.

Pada tahapan pemecahan masalah matematika, siswa dengan kecerdasan logis-matematis tinggi mampu melakukan di setiap tahapan pemecahan masalah (Islami, 2018; Mahardikawati , 2017). Sejalan dengan penelitian Faizah (2017) yang menyimpulkan bahwa siswa dengan kecerdasan logis-matematis yang tinggi mampu memahami masalah dengan baik, mampu menentukan strategi yang tepat untuk memecahkan masalah, menentukan penyelesaian dari permasalahan dengan tepat, dan yakin dan percaya diri terhadap kebenaran dari hasil pekerjaannya, serta melakukan tahapan pemeriksaan kembali terhadap jawaban yang diperoleh.

Mahasiswa dengan kecerdasan logis matematis sedang mempunyai proses berpikir asimilasi dan akomodasi. Sesuai dengan hasil penelitian (Kurniawan \& Mulyati, 2017;Safrida, Susanto, Kurniati : 2015 ) mahasiswa dengan kecerdasan logis sedang mengalami disequilibrium ketika memahami masalah dan menyusun rencana pada salah satu soal, namun sebagian besar mengalami asimilasi dan akomodasi, meski mengalami disequilibrium terlebih dahulu pada 
langkah melaksanakan rencana dan melihat kembali. (Gunawan, 2011) mengungkapkan, bahwa orang yang memiliki kecerdasan logis-matematis yang berkembang dengan baik mampu menunjukkan kemampuan pemecahan masalah. Berdasarkan langkah-langkah yang dilakukan, tampak bahwa mahasiswa sedang ini tidak mampu melakukan pemecahan masalah dengan baik. Dengan demikian, dapat dikatakan bahwa kecerdasan logis-matematis yang dimiliki belum berkembang dengan baik. Mahasiswa dengan kecerdasan logis matematis rendah mempunyai proses berpikir akomodasi. Proses berpikir siswa dengan kecerdasan logis matematis rendah dalam menyelesaikan soal cenderung pada proses berpikir komputasional, tidak mampu mengklasifikasikan informasi secara keseluruhan dari soal, dalam mengklasifikasikan informasi, menunjukkan kekurang pemahaman terhadap masalah yang diberikan (Hasanah, Wardatul \& Siswono, 2013). (Gunawan, 2011) mengungkapkan, bahwa orang yang memiliki kecerdasan logis-matematis yang berkembang dengan baik mampu menunjukkan kemampuan pemecahan masalah. Berdasarkan langkah-langkah yang dilakukan, tampak bahwa mahasiswa dengan kecerdasan logis matematis rendah tidak mampu melakukan pemecahan masalah dengan tepat. Sesuai dengan penelitian (Ersoy \& Guner, 2015) yang menyatakan bahwa tidak semua siswa mampu membuat rencana pemecahan masalah dengan tepat.

Oleh karena itu penting bagi guru atau dosen mengetahui proses berpikir siswa ataupun mahasiswa dalam pemecahan masalah matematis agar dapat mengetahui sejauh mana siswa atau mahasiswa dapat memahami materi, dan memetakan permasalahan yang dihadapi siswa atau mahasiswa dalam rangka untuk menyusun suatu pembelajaran yang sesuai dengan kebutuhan.

\section{KESIMPULAN DAN SARAN}

Berdasarkan hasil penelitian yang telah dilakukan, dapat disimpulkan bahwa dalam menyelesaikan masalah matematika ekonomi, mahasiswa dengan kecerdasan logis matematis tinggi pada tahap memahami masalah, merencanakan penyelesaian, melaksanakan penyelesaian, dan melihat kembali melakukan proses berpikir asimilasi. Proses berpikir mahasiswa dengan kecerdasan logis matematis sedang dalam memahami masalah dan merencanakan masalah melakukan proses berpikir asimilasi, sedangkan untuk melaksanakan rencana penyelesaian dan melihat kembali melakukan proses berpikir akomodasi. Kemudian untuk mahasiswa dengan kecerdasan logis matematis rendah dalam memahami masalah, merencanakan penyelesaian, melaksana-kan rencana penyelesaian dan melihat kembali melakukan proses berpikir akomodasi.

Berdasarkan kesimpulan dari hasil penelitian ini, maka dapat diberikan saran kepada dosen bahwa untuk mengasah proses berpikir mahasiswa dalam memecahkan masalah matematika ekonomi dosen dapat memperbanyak pemberian latihan pemecahan masalah matematis dengan memperhatikan proses berpikir untuk mendapatkan jawaban yang benar. Kemudian untuk penelitian selanjutnya dapat disarankan untuk melakukan penelitian lebih lanjut berkaitan dengan kemampuan pemecahan masalah dan kecerdasan logis matematis mahasiswa sebagai salah satu solusi dalam meningkatkan kemampuan pemecahan masalah matematis pada mata kuliah matematika ekonomi. 
DOI: https://doi.org/10.24127/ajpm.v9i4.3124

\section{DAFTAR PUSTAKA}

Ahvan, Y. R., Pour, H. Z. (2016). The Correlation of Multiple Intelligences for The Achievements of Secondary Students. Academic Journals, 11(4), 141-145.

Arum, D.P., Kusmayadi, T. A., \& Pramudya, I. (2018). Students' logical-mathematical intelligence profile. IOP Conf. Series: Journal of Physics, 1008 (2018, 1-8.

Eka, K \& Mulyati, S. (2017). Proses Asimilasi Dan Akomodasi Dalam Memecahkan Masalah Matematika Berdasarkan Kecerdasan Emosional. Jurnal Pendidikan: Teori, Penelitian, Dan Pengembangan, 2(5), 592-598.

Chatib, M. (2013). Orang Tuanya Manusia. Bandung : Kaifa.

Ersoy, E., Guner, P. (2015). The Place of Problem Solving and Mathematical Thinking in The Mathematical Teaching. The Online Journal of New Horizons in Education, 5(1), 120-130.

Faizah, F., Sujadi, I \& Setiawan, R. (2017). Proses Berpikir Siswa Kelas VII E Dalam Memecahkan Masalah Matematika Pada Materi Pecahan Ditinjau Dari Kecerdasan Logis-Matematis. Jurnal Pendidikan Matematika dan Matematika (JPMM,) I(4), 15-25

Gunawan, A. W. (2011). Born To Be A Genius. Jakarta: Gramedia Pustaka Utama.

Hamzah, B. dan M. K. (2010). Mengelola Kecerdasan dalam Pembelajaran. Jakarta: Bumi Aksara.

Hasanah, Wardatul \& Siswono, T. Y. E. (2013). Kecerdasan LogisMatematis Siswa Dalam Memecahkan Masalah Matematika Pada Materi Komposisi Fungsi. MATHEdunesa, 2(2).
Iskandar. (2012). Psikologi Pedidikan (Sebuah Orientasi Baru). Jakarta: Referensi.

Kamsari \& Winarso, W. (2018). Implikasi Tingkat Kecerdasan Logika Matematika SIswa Terhadap Pemecahan Masalah Matematika. EduSains: Jurnal Pendidikan Sains \& Matematika, 6(1), 44-52.

Karamikabir N. (2012). Gardner's Multiple Intelligence and Mathematics Education. Procedia Social and Behavioral Sciences, 31, 778-781.

Khamidah, K \& Suherman, S. (2016). Proses Berpikir Matematis Siswa dalam Menyelesaikan Masalah Matematika Ditinjau dari Tipe Kepribadian Keirsey. Al-Jabar: Jurnal Pendidikan Matematika, 7(2), 231 - 248

Kurniawan, et al. (2017). Proses Asimilasi Dan Akomodasi Dalam Memecahkan Masalah Matematika Berdasarkan Kecerdasan Emosional. Jurnal Pendidikan: Teori, Penelitian, Dan Pengembangan, 2(5), 592-598

Mukarromah, L. (2019). Kecerdasan Logis Matematis Siswa Dalam Menyelesaikan Masalah Matematika Melalui Problem Posing Pada Materi Himpunan Kelas VII MTS Nurul Huda Mojokerto. JP3, 14(8).

Lunenburg $\mathrm{F} \mathrm{C}$ and Lunenburg $\mathrm{M} \mathrm{R}$. (2014). Applying Multiple Intelligences in The Classroom: A Fresh Look at Teaching Writing. Int $J$ of Scholarly Academic Intellectual Diversity, 16, 1-13.

Masfingatin, T. (2013) Proses Berpikir Siswa Sekolah Menengah Pertama Dalam Memecahkan Masalah Matematika Ditinjau Dari Adversity Quotient. Jurnal Ilmiah Pendidikan Matematika,2(1), 1-8 
Muhtarom, M, Y. H., \& Sutrisno. (2017). Thinking process of students with high-mathematics ability: (a study on QSR NVivo 11-assisted data analysis). International Journal of Applied Engineering Research, 12(17), 6934-6940.

Mukarromah, L. (2019). Kecerdasan Logis Matematis Siswa Dalam Menyelesaikan Masalah Matematika Melalui Problem Posing Pada Materi Himpunan Kelas VII MTS Nurul Huda Mojokerto. Journal of Chemical Information and Modeling, 14(8), 2337-6384.

Nafi' an and Ilman, M. (2012). Proses Berpikir Siswa Kelas V Dalam Menyelesaikan Soal Cerita Pada Pokok Bahasan Pecahan Di Sekolah Dasar Khadijah Surabaya. Gramatika, 1(2), 115-119.

Pane, L. Y., Kamid, and A. (2013). Proses Berpikir Logis Siswa Sekolah Dasar Bertipe Kecerdasan Logis Matematis Dalam Memecahkan Masalah Matematika. Edu-Sains, 2(2), 14-21.

Paul, S. (2001). Teori Perkembangan Kognitif Jean Piaget. Yogyakarta: Kanisius.

Rahbarnia F, Hamedian S, and R. F. (2014). A Study on The Relationship Between Multiple Intelligences and Mathematical Problem Solving Based on Revised Bloom Taxonomy. Journal of Interdisciplinary Math, 17, 109-134.

Safrida, L. N., Susanto, S., \& Kurniati, D. (2015). Analisis Proses Berpikir Siswa Dalam Pemecahan Masalah Terbuka Berbasis Polya Sub Pokok Bahasan Tabung Kelas IX SMP Negeri 7 Jember. Kadikma, 6(1), 2538.
Sopamena, P. (2017). Karakteristik Proses Berpikir Mahasiswa Dalam Mengonstruksi Bukti Keterbagian. Jurnal Matematika Dan Pembelajaran, 5(2), 169-192.

Sugiyono. (2013). Metode Penelitian Kuantitatif, Kualitatif dan $R \& D$. Bandung: Alfabeta.

Suhendri, H. (2011). Pengaruh Kecerdasan Matematis-Logis Dan Kemandirian Belajar Terhadap Hasil Belajar Matematika. Formatif: Jurnal Ilmiah Pendidikan MIPA, 1(1), 29-39.

Sumarni. (2017). Peranan UMKM (Usaha Mikro, Kecil Dan Menengah) Terhadap Perekonomian Indonesia. Jurnal Manajemen, 5(1), 138-145.

Umainah, S.P \& Setyowati, R.D. (2020). Proses Berpikir Siswa Dalam Memecahkan Masalah Matematika Berdasarkan Teori Polya Ditinjau Dari Adversity Quotient. Seminar Nasional Matematika Dan Pendidikan Matematika Program Studi Pendidikan Matematika FPMIPATI-Universitas PGRI Semarang, 05, 104-111

Yani, M., Ikhsan, M \& Marwan, M. (2016) Proses Berpikir Siswa Sekolah Menengah Pertama Dalam Memecahkan Masalah Matematika Berdasarkan Langkah-Langkah Polya Ditinjau Dari Adversity Quotient. Jurnal Pendidikan Matematika, 10(1), 43-57

Yogi, A. (2015). Proses asimilasi dan akomodasi mahasiswa bergaya kognitif field independent dalam menyelesaikan masalah. Prosiding Seminar Nasional, 04, 394-403. 